\title{
Ossifying fibroma of the maxilla and tuberous sclerosis complex
}

Figure 1 Multiple cortical tubers

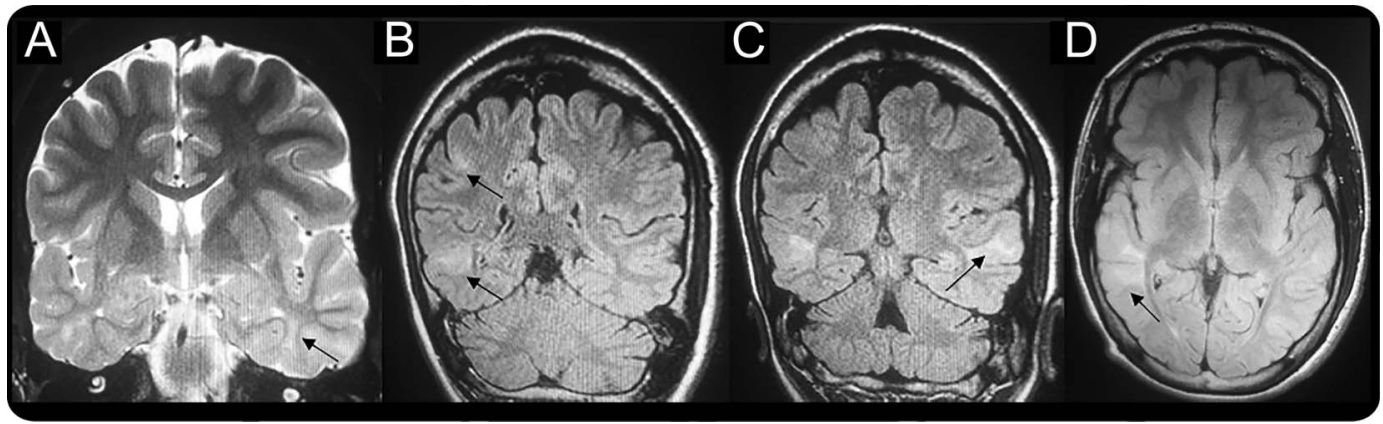

Coronal T2 (A), coronal fluid-attenuated inversion recovery (FLAIR) (B, C), and axial FLAIR (D) weighted brain MRI disclose hyperintense cortical and subcortical areas, compromising temporoparietal regions (black arrow).

A 19-year-old man with refractory generalized epilepsy related to tuberous sclerosis complex (TSC) (figure 1) complained of chronic left facial swelling. Physical examination disclosed typical mucocutaneous findings of TSC (hypomelanotic macules, shagreen patch, ungual fibromas, facial angiofibromas) ${ }^{1}$ and a hardened well-limited mass in his left maxilla, evidenced as an odontogenic extensive left maxillary mass (figure 2). Histopathologic study was compatible with an ossifying fibroma. TSC is a major neurocutaneous syndrome frequently associated with gingival hyperplasia or fibromas. ${ }^{1}$ Ossifying maxillary fibroma is an extremely rare finding associated with TSC. ${ }^{2}$

Wladimir Bocca Vieira de Rezende Pinto, MD, Paulo Victor Sgobbi de Souza, MD, Adrialdo José dos Santos, MD From the Federal University of São Paulo (UNIFESP), Brazil.

Author contributions: W.B.V.R. Pinto: case report project conception, organization, and execution, writing of the first draft, review and critique. P.V.S. de Souza: case report project conception, organization, and execution, writing of the first draft, review and critique. A.J. dos Santos: case report project organization, review and critique.

Study funding: No targeted funding reported.

Disclosure: The authors report no disclosures relevant to the manuscript. Go to Neurology.org for full disclosures.

Correspondence to Dr. Pinto: wladimirburpinto@gmail.com

Figure 2 Paranasal sinus CT scan

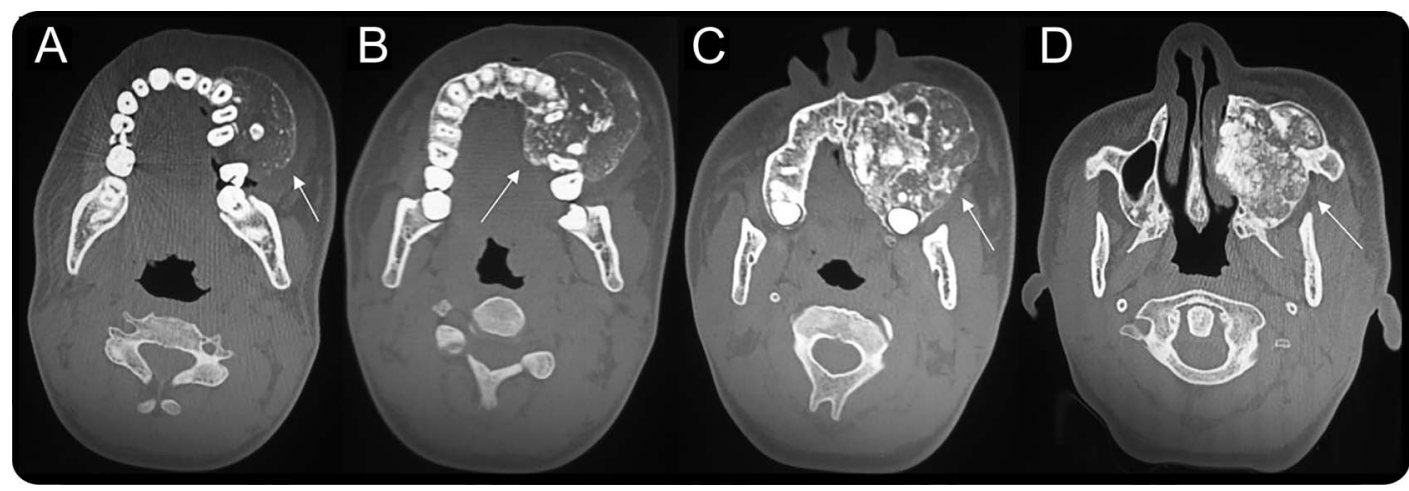

(A-D) Paranasal sinus CT scan discloses an extensive heterogeneous radiolucent lesion extending from left maxilla to the nasal cavity and left maxillary sinus (white arrow). 
1. Krueger DA, Northrup H; on behalf of the International Tuberous Sclerosis Complex Consensus Group. Tuberous sclerosis complex surveillance and management: recommendations of the 2012 international tuberous sclerosis complex consensus conference. Pediatr Neurol 2013;49:255-265.

2. Swarnkar A, Jungreis CA, Peel RL. Central odontogenic fibroma and intracranial aneurysm associated with tuberous sclerosis. Am J Otolaryngol 1998;19:66-69. 


\section{Neurology}

Ossifying fibroma of the maxilla and tuberous sclerosis complex

Wladimir Bocca Vieira de Rezende Pinto, Paulo Victor Sgobbi de Souza and Adrialdo José dos Santos

Neurology 2015;84;1611-1612

DOI 10.1212/WNL.0000000000001478

\section{This information is current as of April 13, 2015}

\section{Updated Information \&} Services

\section{References}

Subspecialty Collections

\section{Permissions \& Licensing}

\section{Reprints}

including high resolution figures, can be found at: http://n.neurology.org/content/84/15/1611.full

This article cites 2 articles, 0 of which you can access for free at: http://n.neurology.org/content/84/15/1611.full\#ref-list-1

This article, along with others on similar topics, appears in the following collection(s):

\section{All Oncology}

http://n.neurology.org/cgi/collection/all_oncology

CT

http://n.neurology.org/cgi/collection/ct

Other neurocutaneous disorders

http://n.neurology.org/cgi/collection/other_neurocutaneous_disorders

Information about reproducing this article in parts (figures,tables) or in its entirety can be found online at:

http://www.neurology.org/about/about_the_journal\#permissions

Information about ordering reprints can be found online:

http://n.neurology.org/subscribers/advertise

Neurology ${ }^{\circledR}$ is the official journal of the American Academy of Neurology. Published continuously since 1951, it is now a weekly with 48 issues per year. Copyright (C 2015 American Academy of Neurology. All rights reserved. Print ISSN: 0028-3878. Online ISSN: 1526-632X.

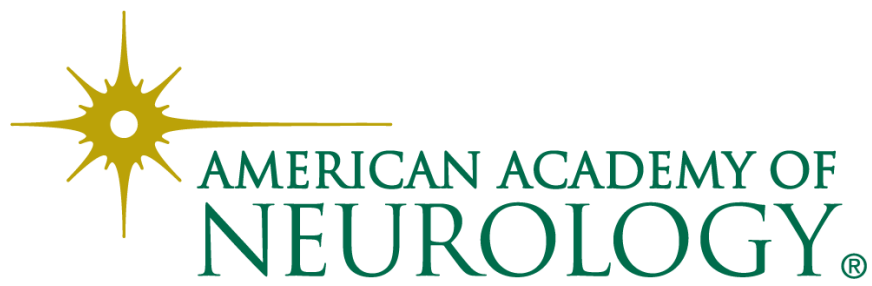

